\title{
Fetal outcome in deliveries with meconium stained liquor
}

\author{
Hemali Pankajbhai Vaghela*, Kruti Deliwala, Parul Shah
}

\author{
Department of Obstetrics \& Gynaecology, Smt. NHL Municipal Medical College, Sheth VS General Hospital, Gujarat \\ University, Ahmedabad-380009, Gujarat, India
}

Received: 22 August 2014

Accepted: 19 September 2014

\author{
*Correspondence: \\ Dr. Hemali Pankajbhai Vaghela, \\ E-mail: drhemalivaghela@gmail.com
}

Copyright: ( $)$ the author(s), publisher and licensee Medip Academy. This is an open-access article distributed under the terms of the Creative Commons Attribution Non-Commercial License, which permits unrestricted non-commercial use, distribution, and reproduction in any medium, provided the original work is properly cited.

\begin{abstract}
Background: Meconium is a dark greenish mass of desquamated cells, mucus, and bile that accumulates in the bowel of a fetus and is typically discharged shortly after birth. Meconium stained amniotic fluid has long been considered to be a bad predictor of fetal outcome. Presence of meconium in amniotic fluid is a potentially serious sign of fetal compromise and associated with poor perinatal outcome. This prospective observational study was undertaken to find out immediate fetal outcome in meconium stained liquor.

Methods: Design: prospective study. This study was conducted from January 2014 to June 2014. The study included women with meconium stained amniotic fluid in labor with gestational age $>37$ completed weeks.

Results: Total 100 cases were enrolled. $67 \%$ were term patient. Majority of the patients (74\%) were in the age group of 21-30 years. Fetal distress occurred in 25\% of babies, more in association with thick meconium (13\%). Cesarean deliveries were $68 \%$. APGAR scores in first minute was severe (0-3) in 5\% and $1 \%$ at fifth minute, moderate (4-6) in $8 \%$ at first minute and was $4 \%$ at fifth minute and mild (7-10) in $86 \%$ at first minute and $94 \%$ at fifth minute. Admission in neonatal ward was $30 \%$ with perinatal mortality of $5 \%$.

Conclusions: Meconium stained amniotic fluid was associated with higher rate of cesarean delivery, increased need for neonatal resuscitation, increased rate of birth asphyxia with hypoxic ischemic encephalopathy, meconium aspiration syndrome, hospital admission and mortality. Meconium stained liquor is more commonly associated with $\mathrm{PIH}$, post-datism, oligohydroamnios and DM.
\end{abstract}

Keywords: Meconium stained liquor, Fetal outcome

\section{INTRODUCTION}

The word meconium is derived from Greek word "meconium arion" which means like opium or poppy like substances causing sleeping like state of the fetus in mother's womb. Presence of meconium in amniotic fluid is a potentially serious sign of fetal compromise and associated with a poor perinatal outcome including low APGAR scores, increased rate of chorioamnionitis, increased incidence of neonatal intensive care admission and high rate of perinatal death. Incidence of meconium passage is less before 34 weeks of gestations and after 37 weeks its incidence increases steadily with increasing gestational age reflecting the maturation of fetal intestinal myelination and parasympathetic innervations. Aspiration can occur in utero with fetal gasping or after birth with the first breaths of life. A large proportion of women with meconium stained liquor have risk factors simultaneously like preeclampsia, diabetes and post maturity. As meconium stained amniotic fluid is associated with lots of adverse outcome of fetus and has long been considered to be a bad predictor of fetal outcome so this observational study was undertaken to find out the correlation between pregnancy and immediate fetal outcome in meconium stained liquor to see the babies needed for immediate resuscitation and improve the fetal outcome in form of perinatal morbidity and mortality. 


\section{METHODS}

A prospective observational study was conducted in obstetrics and gynaecology department of our institution from January 2014 to June 2014 and study population included 100 cases of meconium stained liquor during labor and their outcome in terms of mode of delivery and fetal outcome.

The inclusion criteria were women in labor with

$\checkmark \quad$ Term pregnancy ( >37 weeks gestation)

$\checkmark$ Cephalic presentation

$\checkmark \quad$ Live singleton normal pregnancy

Exclusion criteria were:

$\times$ Pregnant women in labour with not knowing last menstrual date

$\times \quad$ Eclampsia

$\times \quad$ Antepartum hemorrhage

$\times \quad$ Intrauterine fetal death

$\times$ Congenital malformation

$\times \quad$ Pre-existing maternal heart or lung disease

$\times \quad$ Pregnancies with IUGR babies

$\times \quad$ Presentations other than cephalic

Following selection of cases, detailed history was taken and general and systemic examinations were done. Detailed obstetrical examination was undertaken noting the presentation, position, height of fundus, amount of amniotic fluid, fetal heart rate, uterine contractions, and pelvic status. Use of any medications like oxytocin, sedatives, analgesics was also noted. Detailed follow up of the progress of labor was done using partogram to observe whether the progress of labor was coinciding with normal progress. Patients whose progress was smooth according to the partogram were allowed to progress for normal vaginal delivery. Whereas those patients whose progress did not coincide with the partogram were closely observed and artificial rupture of membrane was done at an earlier stage. Also in high risk patients like those with post-datism, oligohydromnios or PIH, early ARM was done. Meconium staining of amniotic fluid was noted during artificial or spontaneous rupture of membranes and its consistency was noted, whether it was thin, moderate or thick. Correlation between cervical dilatation and appearance of meconium in amniotic fluid was noted. Also the fetal heart rate pattern was noted and accordingly the mode of delivery was decided. After birth the newborn was examined by the obstetrician and neonatologist with continuous follow up daily till discharge from the hospital and re-examined after 15 days in OPD. Fetal outcome was measured by APGAR scores at $1^{\text {st }}$ and $5^{\text {th }}$ minutes, weight, sex, requirement of neonatal resuscitation, admission in neonatal ward and intensive care unit. Relevant investigations including chest X-ray were carried out.

\section{RESULTS}

Total 18 cases of meconium stained amniotic fluid were seen during latent phase and all were delivered by cesarean section. In group 2, 45 delivered by cesarean section \& 23 by normal vaginal delivery. In group 3, 9 delivered vaginaly (Table 1 ).

Table 1: Correlation between cervical dilatation and meconium passage with mode of delivery.

\begin{tabular}{|l|llll|}
\hline Group & $\begin{array}{l}\text { Cervical } \\
\text { dilatation } \\
(\mathrm{cm})\end{array}$ & $\begin{array}{l}\text { No. of } \\
\text { cases }\end{array}$ & LSCS & $\begin{array}{l}\text { Mode of delivery } \\
\text { Normal } \\
\text { vaginal } \\
\text { delivery }\end{array}$ \\
\hline 1 & $0-3$ & 18 & 18 & 0 \\
\hline 2 & $4-7$ & 68 & 45 & 23 \\
\hline 3 & $8-10$ & 14 & 5 & 9 \\
\hline
\end{tabular}

The overall incidence of fetal distress in meconium stained amniotic fluid was $25 \%$. Out of which majority (52\%) cases had thick meconium liquor developing fetal distress (Table 2).

Table 2: Correlation between meconium staining and fetal distress.

\begin{tabular}{|lll|}
\hline $\begin{array}{l}\text { Type of } \\
\text { meconium }\end{array}$ & $\begin{array}{l}\text { No. of babies with } \\
\text { fetal distress }\end{array}$ & $\%$ \\
\hline Thin (38) & 3 & 12 \\
\hline Moderate (34) & 9 & 36 \\
\hline Thick (28) & 13 & 52 \\
\hline Total & 25 & 100 \\
\hline
\end{tabular}

In this study one baby was still born. All the new-born babies were immediately resuscitated \& reassessed by 5 minute APGAR score. Out of 13 new-born having APGAR score $<7$ at 1 minute, 8 improved with resuscitation and 5 neonates needed NICU admission (Table 3).

NICU admission was required in 30 cases, 13 cases had thick meconium (Table 4).

This shows $75 \%$ cases had normal fetal heart rate at the time of detection of meconium, $18 \%$ had bradycardia and $7 \%$ had tachycardia (Table 5).

Birth asphyxia, aspiration pneumonia, respiratory distress syndrome and febrile illness contribute to perinatal morbidity. Perinatal mortality was 5\% (Table 6). 
Table 3: Comparison of meconium stained amniotic fluid with APGAR score at 1 and 5 minute.

\begin{tabular}{|c|c|c|c|c|c|c|}
\hline \multirow{3}{*}{$\begin{array}{l}\text { Type of } \\
\text { meconium }\end{array}$} & \multicolumn{6}{|c|}{ APGAR score } \\
\hline & \multicolumn{3}{|l|}{ AT 1 minute } & \multicolumn{3}{|c|}{ AT 5 minute } \\
\hline & $\begin{array}{l}0-3 \\
\text { (severe) }\end{array}$ & $\begin{array}{l}4-6 \\
\text { (moderate) }\end{array}$ & $\begin{array}{l}7-10 \\
\text { (mild) }\end{array}$ & $\begin{array}{l}0-3 \\
\text { (severe) }\end{array}$ & $\begin{array}{l}4-6 \\
\text { (moderate) }\end{array}$ & $\begin{array}{l}7-10 \\
\text { (mild) }\end{array}$ \\
\hline Thin (38) & - & $02(5.26 \%)$ & $36(94.74 \%)$ & - & $01(2.63 \%)$ & $37(97.37 \%)$ \\
\hline Moderate (34) & $02(5.88 \%)$ & $04(11.76 \%)$ & $28(82.35 \%)$ & $00(0 \%)$ & $02(5.88 \%)$ & $32(94.11 \%)$ \\
\hline Thick (28) & $03(11.11 \%)$ & $02(7.4 \%)$ & $22(81.48 \%)$ & $01((3.7 \%)$ & $01(3.7 \%)$ & $25(92.59 \%)$ \\
\hline Total (100) & 05 & 08 & 86 & 01 & 04 & 94 \\
\hline
\end{tabular}

Table 4: Meconium stained liquor and NICU admission.

\begin{tabular}{|lll|}
\hline $\begin{array}{l}\text { Type of } \\
\text { meconium }\end{array}$ & $\begin{array}{l}\text { No. of } \\
\text { cases }\end{array}$ & $\begin{array}{l}\text { NICU } \\
\text { admission }\end{array}$ \\
\hline Thin & 38 & 04 \\
\hline Moderate & 34 & 13 \\
\hline Thick & 28 & 13 \\
\hline Total & 100 & 30 \\
\hline
\end{tabular}

Table 5: Correlation between fetal heart rate and degree of meconium stained liquor.

\begin{tabular}{|lllll|}
\hline FHIR/min & No. of & \multicolumn{3}{l|}{ Degree of meconium } \\
cases & Thin & Moderate & Thick \\
\hline$<90$ & 4 & 0 & 2 & 3 \\
\hline $90-120$ & 14 & 3 & 5 & 6 \\
\hline $120-160$ & 75 & 35 & 24 & 15 \\
\hline$>160$ & 7 & 0 & 3 & 4 \\
\hline Total & 100 & 38 & 34 & 28 \\
\hline
\end{tabular}

Table 6: Meconium stained amniotic fluid and perinatal morbidity and mortality.

\begin{tabular}{|llllll|}
\hline Perinatal morbidity & Thin & Moderate & Thick & Total & $\begin{array}{c}\text { Perinatal } \\
\text { mortality }\end{array}$ \\
\hline Birth asphyxia & 0 & 1 & 4 & 5 & 1 \\
\hline Aspiration pneumonia & 3 & 1 & 1 & 5 & 2 \\
\hline Respiratory distress syndrome & - & 2 & 3 & 5 & 1 \\
\hline Febrile illness & 1 & 2 & 2 & 5 & 1 \\
\hline Infection/septicemia & - & 3 & 1 & 4 & 0 \\
\hline Hypoxic ischemic encephalopathy & 0 & 1 & 2 & 3 & 0 \\
\hline Jaundice & - & 1 & 2 & 3 & 0 \\
\hline Convulsion & - & 1 & 1 & 2 & 0 \\
\hline
\end{tabular}

\section{DISCUSSION}

This study was done to find out the fetal outcome of those deliveries where liquor was meconium stained and to determine the risk of adverse fetal outcome associated with meconium stained amniotic fluid. Majority of the patients $(74 \%)$ were in the age group 21-30 years. Neke Akhtar et al., ${ }^{1}$ showed that the mean age of mother was $26.2 \pm 5.2$ years. In present study $67 \%$ of the patients with meconium stained amniotic fluid were term patients. Gupta et al. ${ }^{2}$ found significant increased rate $(86.7 \%)$ of meconium in amniotic fluid after 37 weeks. Oyelese Y et al. $^{3}$ also proposed similar findings. Present study shows birth weight of $2.6-3 \mathrm{~kg}$ in majority of patients. Sedaghatian et al. ${ }^{4}$ observed similar result in their study. Neke at al. ${ }^{1}$ found that $77.5 \%$ babies had birth weight $>2.5 \mathrm{~kg}$. In our study $38 \%$ patients had thin meconium, $34 \%$ had moderate, $28 \%$ had thick meconium. Erum Majid Sheikh et al. ${ }^{5}$ and Piper et al. ${ }^{6}$ observed similar findings. In present study $59 \%$ patients had associated obstetric risk factors like PIH, post-datism, oligohydroamnios, PROM. Out of this $13 \%$ patients had PIH. Bhide et al. ${ }^{7}$ found $13.8 \%$ having PIH. In present study, $75 \%$ cases had normal fetal heart rate at the time of detection of meconium, $18 \%$ had bradycardia \& $7 \%$ had tachycardias which were similar with the findings of Berkus et al. ${ }^{8}$ who observed significantly higher risk of an abnormal fetal heart rate in meconium stained group. Sasikala et al. ${ }^{9}$ found that $26.2 \%$ had fetal bradycardia \& $6.5 \%$ had tachycardia. In present study, APGAR score in first minute was low $(<7)$ in $5.26 \%$ patients with thin meconium as compared to $18.51 \%$ of patients with thick meconium. Sedaghatian et al. ${ }^{4}$ found similar result in their study. Patil KP et al. ${ }^{10}$ observed that $6.74 \%$ of patients with thin meconium and $26.25 \%$ of patients with thick meconium had low $(<7)$ APGAR score. Mode of delivery was significantly influenced by the presence of meconium stained amniotic fluid. Cesarean deliveries were high (68\%), more with thick meconium. Neke et al. ${ }^{1}$ also showed comparable results. Chishty AL et al. ${ }^{11}$ 
observed $62 \%$ of cesarean section rate. Even in places where other facilities of intrapartum monitoring like fetal blood sampling and cardiotocography are available, the rate of caesarian delivery are found to be increased. Gupta et al. ${ }^{2}$ found that birth asphyxia was significantly high in meconium stained amniotic fluid. Khatun $\mathrm{M}$ et al. $^{12}$ found $12.9 \%$ birth asphyxia cases in her study. Whereas present study showed $19.23 \%$ developed birth asphyxia. This was comparable to the study conducted by Usha et al. ${ }^{13}$ where perinatal morbidity was $32 \%$. Higher chances of IUGR \& intrapartum asphyxia (APGAR score <7) was noted in babies born to mother having snoring \& sleep disordered breathing. Aggarwal et al. ${ }^{14}$ observed similar findings. In present study mortality rate was $3 \%$ in cases with thick meconium and $2 \%$ in cases of thin meconium. Khatun $\mathrm{M}$ et al. ${ }^{13}$ found $2.9 \%$ mortality in meconium stained amniotic fluid with thick meconium. Gupta et al. ${ }^{2}$ found $4.9 \%$ mortality in meconium stained amniotic fluid.

\section{CONCLUSION}

Meconium stained amniotic fluid is associated with increased need for neonatal resuscitation, increased risk of birth asphyxia, meconium aspiration syndrome, hospital admission and mortality. So identification of pregnant woman at risk of passage of meconium during labour would allow intensive fetal surveillance and early intervention which might lead to reduction in neonatal adverse outcome. Neonatal expertise at the time of delivery with equipments like oxygen mask, laryngoscope, suction catheter, endotracheal tube \& AMBU bag should be present and advanced neonatal resuscitation unit is required to decrease fetal morbidity and hence mortality in patients with meconium stained amniotic fluid.

\section{ACKNOWLEDGEMENTS}

We hereby would like to thank Dr. S. T. Malhan, the superintendent of Sheth V. S. general hospital, Dr. Pankaj R. Patel, the dean of Smt N.H.L. municipal medical college to allow us to publish this paper.

Funding: No funding sources

Conflict of interest: None declared

Ethical approval: The study was approved by the institutional ethics committee

\section{REFERENCES}

1. Neke Akhtar, Fazilatunnesa, Sharmeen Yasmean. Mode of delivery and fetal outcome in meconium stained amniotic fluid in DMCH, 2006. Available at:
www.jemds.com/data_pdf/Dr\%20Uday\%20Rajput2.doc.

2. Gupta V, Bhatia BD, Mishra OP. Meconium stained amniotic fluid: Antenatal intrapartum and neonatal attributes. Indian Paediatr. 1996;33:293-7.

3. Oyelese Y, Culin A, Ananth CV, Kaminsky LM, Vintzileos AM, Smulian JC. Meconium-stained amniotic fluid across gestation and neonatal acidbase status. Am J Obstet Gynaecol. 2006;108:345-9.

4. Sedaghatian MR, Otheman L, Rashid N, Ramachandran P, Bener BA. An 8 year study of meconium stained amniotic fluid in different ethnic groups. Kuwait Med J. 2004;36:266-9.

5. Erum Majid Sheikh, Sedaf Mehmood, Majed ahmed sheikh. Neonatal outcome in meconium stained amniotic fluid: one year experience. J Pak Med Assoc. 2010 Sep;60(9):711-4.

6. Piper JM, Newton ER, Berkus MD, Peairs WA. Meconium a marker of peripartum infection. Obstet Gynaecol (USA). 1998;91(5 Pt.1):741-5.

7. Bhide SS, Shendurnikar N, Aiyer S, Baxi SR. Neonatal outcome after meconium stained amniotic fluid. J Obstet Gynaecol India. 1994;48:933-5.

8. Berkus MD, Langer O, Samuelloff A, Zenakis EM, Field NT, Ridgeway LE. Meconium stained amniotic fluid: Increased risk for adverse neonatal outcome. Obstet Gynaecol. 1994;84:115-20.

9. Sasikala A, Raghwan S, Mishra N, Khatun S, Bupathi A, Rani NR. Perinatal outcome in relation to mode of delivery in meconium stained amniotic fluid. Indian J Paediatr. 1995;62(1):63-7.

10. Patil KP, Swamy MK, Samatha K. A one year cross sectional study of management practices of meconium stained amniotic fluid and perinatal outcome. Obstet Gynaecol India. 2006;56:128-30.

11. Chishty AL, Alvi Y, Iftikhar M, Bhutta TI. Meconium aspiration in neonates: combined obstetrics and pediatric intervention improves outcome. J Pak Med Assoc. 1996 May;46(5);104-8.

12. Khatun M. Meconium Staining liquor and its correlative with fetal outcome within seven days of birth in Dhaka medical college. Dissertation. Bangladesh Coll Physicians Surgeons. 2005;2:39-43.

13. Usha Sharma, Kamala Gokhroo, Mamta Sharma. Perinatal outcome in meconium stained amniotic fluid. As J Obstel Gynaecol Practice. 2004;8(4):3740

14. Aggarwal Manju, Suri JC, Suri Sushma, Sen MK. Maternal \& fetal outcome of sleep disordered breathing in pregnancy. Indian $\mathbf{J}$ Sleep Med. 2008;3(1):25-9.

DOI: $10.5455 / 2320-1770 . i j r \operatorname{cog} 20141207$

Cite this article as: Vaghela HP, Deliwala K, Shah $\mathrm{P}$. Fetal outcome in deliveries with meconium stained liquor. Int J Reprod Contracept Obstet Gynecol 2014;3:909-12. 